PENGAMBILAN KEPUTUSAN DALAM ORGANISASI LEMBAGA PENDIDIKAN

\author{
Budiono \\ 18510000 \\ Fakultas Komputer \\ budiono.student@umitra.ac.id
}

\begin{abstract}
MTs Al Falah Cicalengka Kabupaten Bandung adalah lembaga pendidikan Islam yang menggunakan prosedur dan kebijakan pengambilan keputusan yang mengacu pada hukum dan peraturan yang berlaku. tujuan dari penelitian ini adalah untuk menentukan proses dasar dari kebijakan pengambilan keputusan, terutama di bidang manajemen pembiayaan di lembaga terkait. Penelitian ini menggunakan metode deskriptif kualitatif. Keputusan adalah tahap paling penting dalam pengelolaan lembaga pendidikan Islam, karena ini merupakan penentu kemajuan dan penarikan lembaga pendidikan.
\end{abstract}

Keywords: Taking, decision, in Institution, Education 
A. PENDAHULUAN

Setiap tindakan manusia seharihari, selalu didasari oleh keputusan yang diambil. Mulai aktivitas individual hingga aktivitas dalam organisasi, semuanya didasari pada keputusan yang telah ditetapkan sebelumnya. Akan tetapi, karena keputusan-keputusan tersebut telah rutin diambil, kita biasanya tidak lagi berfikir lama untuk menetapkan keputusan tersebut. Setiap tindakan seolah-olah dilakukan begitu saja secara alami tanpa perlu pertimbangan.

Diluar tindakan rutin tersebut,permasalahan yang perlu dipertimbangkan matangmatang sebelum mengambil keputusan. Hal ini dikaenakan keputusan yang dibuat harus didasari pada pertimbangan matang dari berbagai kemungkinan yang ada.

Keputusan untuk memilih ini tidak selalu mudah, terutama karena kita mempunyai berbagai keterbatasan. Apabila dengan keterbatasan tersebut kita paksa untuk mendapatkan sesuatu yang sangat ideal, tidak jarang keputusan tersebut menjadi salah. Akibatnya kita harus menanggung resiko memilih pilihan yang kurang tepat sehingga merugikan diri sendiri maupun organisasi.

Berdasarkan pemaparan di atas, maka peneliti mengambil keputusan untuk menentukan lokasi penelitian di MTs Al Falah Cicalengka Kabupaten Bandung. MTs Al falah merupakan lembaga pendidikan islam yang refresentatif untuk di jadikan objek penelitian karena menjadi lembaga yang diminati oleh masyarakat yang memang dianggap sebagai lembaga pendidikan islam yang memiliki program pendidikan islam yangf maju dan menghasilkan output pendidikan yang berkualitas sebagai bentuk pengambilan keputusan dan kebijakan lembaga pendidikan islam yang sedang di kaji oleh peneliti.

Berdasarkan latar belakang masalah di atas, maka kami merumuskan masalah sebagai berikut: Bagaimanakah konsep dasar pengambilan keputusan, Bagaimanakah kebijakan dasar pengambilan keputusan di MTs Al Falah Cicalengka Kabupaten Bandung, Bagaimanakah gaya dan model pengambilan 
keputusan di MTs Al Falah Cicalengka Kabupaten Bandung, Bagaimanakah model pengambilan keputusan partisipatif dalam kepemimpinan di MTs Al Falah Cicalengka Kabupaten Bandung. mengingat kajian penelitian ini sangat luas, amaka peneliti membatasi masalah pada dasar kebijakan pengambilan keputusan di bidang pengelolaan pembiyaan.

B. KAJIAN TEORITIK TENTANG PENGAMBILAN KEPUTUSAN DALAM ORGANISASI LEMABAGA PENDIDIKAN

\section{Konsep Dasar Pengambilan Keputusan}

Dilihat dari segi pengertiannya, keputusan adalah pemutusan satu pengakhiran dari proses pemikiran tentang satu masalah atau problem, untuk menjawab pertanyaan apa yang harus diperbuat guna mengatasi masalah tersebut, dengan menjadikan pilihan pada salah satu alternatif tertentu.

Siagian mendefinisikan pengambilan keputusan sebagai usaha sadar untuk menentukan satu alternatif dari berbagai alternatif untuk memecahkan masalah. (Siagian, 1993, p. 24). Salusu mendefinisikan pengambilan keputusan sebagai proses memilih suatu alternatif cara bertindak dengan metode yang efisien sesuai setuasi untuk menemukan dan menyelesaikan masalah organisasi. (Salusu, 1996, p. th). Handoko mendefinisikan pengambilan keputusan sebagai proses pemilihan serangkaian kegiatan di pilih sebagai penyelesaian suatu masalah tertentu.(Handoko, 2011, p. 11). Rusdiana menjelaskan bahwa pengambilan keputusan sangat erat hubungannya dengan seluruh kegiatan organisasi,dan meliputi seluruh fungsi manajemen dalam organisasi. Lembaga pendidikan pun tidak terlepas dari pengambilan keputusan itu sendiri, baik pengambilan keputusan pada tingkat sederhana maupun pada tingkat yang sulit sesuai dengan alternatif yang di gunakan.(Rusdiana, 2016, p. 202).

\section{Prinsip-prinsip Pengambilan Keputusan dalam Organisasi}

Prinsip-prinsip dari pengambilan keputusan menurut Piet Saher Tian adalah sebagai berikut (Piet Saher Tian, 1994, th):

a. Dapat di bedakan dengan jelas antara pengambilan keputusan dengan pemecahan masalah;

b. Pengambilan keputusan harus selalu dilihat dalam 
kaitannya dengan tujuantujuan yang hendak di capai;

c. Sebab pengambilan keputusan sering mengandung faktor mereka maka selalu diperlukan data penunjang dan analisa yang konprehensif dalam mengambil suatu keputusan.

d. Pinpinan tidak haya mau mengambil keputusan, tetapi juga bertanggung jawab atas segala tindakan keputusan itu.

\section{Fungsi Pengambilan Keputusan}

Fungsi pengambilan keputusan, yaitu sebagai berikut:

a. Pangkal permulaan dari semua aktivitasi manusia yang dasar dan terarah, baik secara individu atau kelompok, baik secara institusional maupun secara organisasional.

b. Sesuatu yang bersifat futuristik, yaitu berkaitan dengan hari depan, masa yang akan datang yang efeknya atau pengarahanya berlangsung cukup lama.

Tujuan Pengambilan Keputusan

Rusdiana menjelaskan, tujuan dari pengambilan keputusan adalah sebagai berikut (Rusdiana, 2016, p. 204):

a. Tujuan yang bersifat tunggal, terjadi apabila keputusan yang di hasilkan hanya menyangkut satu masalah. Artinya, sekali diputuskan tidak akan ada kaitannya dengan masalah lain.

b. Tujuan yang bersifat ganda, terjadi apabila keputusan yang di ambil sekaligus memecahkan dua masalah atau lebih yang bersifat kontradiktif atau yang tidak kontradiktif.

\section{Unsur-unsur}

Pengambilan

\section{Keputusan}

Menurut Ibnu Syamsi (1995) dalam Rusdiana (Rusdiana, 2016, p. 205), unsur-unsur pengambilan keputusan yang harus di pertimbangkan adalah sebagai berikut:

a. Tujuan dari pengambilan keputusan, yaitu mengetahui terlebih dahulu tujuan yang ingin di capai dari pengambilan keputusan tersebut.

b. Identifikasi alternatifalternatif keputusan untuk memecahkan masalah yang di pilih 
untuk mencapai tujuan tersebut.

c. Perhitungan mengenai faktor-faktor yang tidak dapat diketahui sebelumnya atau di luar jangkauan manusia.

d. Sarana atau alat untuk mengevaluasi atau mengukur hasil dari suatu pengsambilan keputusan.

Faktor-faktor

Mempengaruhi

yang

Keputusan

Faktor-faktor

yang

mempengaruhi

pengambilan

keputusan, menurut Eti Rodiaty (2008) yang di kutip oleh Rusdiana adalah sebagai berikut:

a. Kedudukan

Dalam kerangka pengambilan keputusan, posisi/kedudukan seseorang dapat dilihat dalam hal letak posisinya, apakah sebagai pembuat keputusan (decision maker), penentu keputusan (decision taker), ataukah staf (staffer).

b. Masalah

Atau problem adalah hal-hal yang menjadi penghalang untuk tercapainya tujuan, yang merupakan penyimpangan dari hal-hal yang diharapkan, direncanakan atau dikhendaki dan harus di selesaikan. c. Situasi

Situasi adalah keseluruhan faktor dalam keadaan, yang berkaitan satu sama lain, dan secara bersama-sama memancarkan pengaruh terhadap kita beserta apa yang hendak kita perbuat

d. Kondisi

Kondisi adalah keseluruhan dari paktor yang secara bersama-sama menentukan daya gerak, daya berbuat, atau kemampuan kita. Sebagian besar paktor tersebut merupakan sember daya.

e. Tujuan

Tujuan yang hendak dicapai, baik tujuan perseorangan, tujuan unit (kesatuan), tujuan organisasi maupun tujuan usaha, pada umumnya telah di tentukan. Tujuan yang di tentukan dalam prengambilan keputusan merupakan tujuan antara atau onbjektif.

\section{ID SECURITY}

QWTD445377-ASP-5244107

\section{Proses dan Tahapan Pengambilan Keputusan dalam Organisasi Pendidikan}

Dalam pemecahan masalah menurut Handoko dalam buku rusdiana (Rusdiana,2016, p. 217) proses pengambilan keputusan 
secara rasional dan ilmiah pada dasarnya meliputi tahapan sebagai berikut:

a) Mengidentifikasi masalah

b) Merumuskan masalah

c) Menentukan alternatif

d) Mengidentifikasi akibat atau konsekuensi dari pengambilan keputusan setiap alternatif

e) Memilih alternatif yang baik Evaluasi

Menurut Herbart A. Simon dalam Rusdiana (Rusdiana, 2016, p. 220), tiga tahap yang ditempuh dalam pengambilan keputusan, yaitu sebagai berikut:

1. Tahap penyelidikan, yaitu mempelajari lingkungan terhadap kondisi yang memerlukan keputusan. Pada tahap ini data mentah yang diperoleh, diolah, dan diuji serta dijadikan petunjuk untuk mengetahui atau mengenal persoalan.

2. Tahap perancangan, yaitu pendaftaran, pengembangan, penganalisaan arah tindakan yang mungkin dilakukan.

3. Tahap pemilihan, yaitu kegiatan pemilihan arah tindakan dari semua yang ada.

Model Pengambilan Keputusan Partisipatif dalam Kepemimpinan Organisasi Lembaga Pendidikan Karakteristik Model Pengambilan Keputusan dalam Kepemimpinan Partisipatif
Para teoretikus mengemukakan empat prosedur pengambilan keputusan, yang menurut Yukl dalam Rusdiana (2016:220), merupakan kontinum yang digambarkan sebagai berikut(Rusdiana, 2016, p. 222)

\section{Kelebihan \\ Pengambilan \\ Keputusan Partisipatif}

Menurut Yukl (1991) dalam Rusdiana (Rusdiana, 2016, p. 222), beberapa keuntungan potensial pengambila keputusan, yaitu sebagai berikut:

a. Meningkatkan kualitas sebuah keputusan apabila anggota organisasi mempunyai informasi dan pengetahuan yang tidak dimiliki pemimpin tersebut dan bersedia bekerja sama dalam mencari suatu pemecahan yang baik untuk suatu masalah keputusan.

b. Secara khusus kelebihan kepemimpinan partisipatif, yaitu sebagai berikut.

1) Konsultasi ke bawah

2) Konsultasi lateral

3) Konsultasi ke atas

4) Konsultasi dengan pihak luar

\section{Efektifitas Model Pengambilan Keputusan Partisipatif}

Efektivitas keseluruhan dari sebuah keputusan bergantung pada dua variabel intervensi, yaitu penerimaan keputusan dan kualitas keputusan adalah sebagai berikut: 
a. Orang-orang yang mempunyai pengaruh yang cukup besar dalam pengambilan keputusan cenderung mengidentifikasikan dirinya dengan hal tersebut dan merasakannya sebagai keputusannya.

b. Partisipasi juga member pengertian yang lebih baik mengenai sifat masalah keputusan dan alasan mengapa suatu altternatif tertentu diterima dan yang lainnya ditolak.

c. Memungkinkan orang memperoleh peluang untuk melindungi kepentingan mereka jika benar-benar terancam.

d. Sebuah keputusan yang telah dibuat oleh sebuah proses kelompok yang dianggap sah.

\section{Keterbatasan}

Pengambilan

\section{Keputusan Partisipatif}

Pengambilan keputusan partisipatif memiliki keterbatasan sebagai berikut:

a. Memerlukan banyak waktu, kadang bertele-tele, dalam keadaan darurat untuk berkonsultasi dan berdiskusi tidak efektif, pemimpin harus cepat dan tanggap dalam mengambil keputusan.

b. Terjadinya partisipasi semu (pseudoparticipation), yaitu pemimpin mencoba untuk melibatkan bawahan dalam tugas, bukan dalam proses pengambilan keputusan.
Implementasi Model Pengambilan Keputusan Partisipatif dalam Kepemimpinan Organisasi

\section{Pendidikan}

Mengenai implementasi pengambilan keputusan dalam kepemimpinan partisipatif dalam kepemimpinan pendidikan berkaitan erat dengan perilaku birokrasi pendidikan, kepala sekolah, dan guru sebagai anggota organisasi pendidikan dalam pengambilan keputusan. Peran serta ketiga pemimpin pendidikan dalam pengambilan keputusan ditegaskan oleh French (1960) dalam Rusdiana (Rusdiana, 2016, p. 226) bahwa peran serta menunjukkan suatu proses antara dua atau lebih pihak yang mempengaruhi satu terhadap yang lainnya dalam membuat rencana, kebijaksanaan dan keputusan.

Adanya peran serta ada jaminan bahwa anggota organisasi pendidikan tetap mempunyai control atas keputusan-keputusan yang diambil, yaitu sebagai berikut:

a. Peran pemimpin pendidikan dalam pengambilan keputusan partisipatif.

b. Peran bawahan dalam pengambilan keputusan.

Adapun menurut Amirullah Haris Budiyana mengatakan bahwa teori manajemen mengenal perbedaan antara dua model utama dalam pembuatan keputusan. Kedua model tersebut adalah mode klasik 
dan model perilaku (Amirullah Haris Budiyana, 2004, p. 153).

\section{Faktor Faktor yang mempengaruhi dasar kebijakan pengambilan keputusan}

Secara umum faktor yang mempengaruhi pengambilan keputusan di MTs Al Falah Cicalengka Kabipaten bandung khususnya dalam kebijakan pembiayaan madrasah adalah jabatan dan setruktur organisasi. dimana dalam setiap pengambilan keputusan dan kebijakan selalu mengakomodir rekomendasi dari pengurus yayasan asyahidiyah. karena sekolah ini berada di bawah yayasan tersebut sehingga dalam setiap pengambilan keputusan serta kebijakan sangat tergantung kepada kebijakan yayasan.

Selain dari itu, proses pengambilan kebijakan yang bersifat setrategis juga selalu mempertimbangkan aspek budaya organisasi dan dengan persetujuan komite madrasah serta arah kebijakan yayasan, kewenangan kepala madrasah yang memang sangat terbatas, sehingga kepala madrasah selalu berhati hati dan memperhatikan seluruh aspek serta kepentingan pemilik yayasan.

\section{E. KESIMPULAN}

Berdasarkan kajian teori dan hasil penelitian serta pembahasan hasil penelitian maka dapat disimpulkan bahwa kebijakan dasar pengambilan keputusan di MTs A 1 Falah Cicalengka Kabupaten Bandung merupakan proses penyusunan program baik jangka pendek, menengah, maupun jangka panjang. selain dari itu pengambilan kebijakan dan keputusan dilakukan untuk menyelesaikan berbagai masalah yang di hadapi lembaga. kemudian faktor utama yang mempengaruhi pengambilan kebijakan adalah adanya keterbatasan wewenang kepala sekoalh yang berada di bawah yayasan.

\section{F. REFERENCE}

[1] O. M. Febriani and A. S. Putra, "Sistem Informasi Monitoring Inventori Barang Pada Balai Riset Standardisasi Industri Bandar Lampung," J. Inform., vol. 13, no. 1, pp. 90-98, 2014.

[2] A. S. Putra, "Paperplain: Execution Fundamental Create Application With Borland Delphi 7.0 University Of Mitra Indonesia," 2018.

[3] A. S. Putra, "2018 Artikel Struktur Data, Audit Dan Jaringan Komputer," 2018.

[4] A. S. Putra, "ALIAS MANAGER USED IN DATABASE DESKTOP 
STUDI CASE DB

DEMOS."

[5] A. S. Putra, "COMPREHENSIVE SET OF PROFESSIONAL FOR DISTRIBUTE COMPUTING."

[6] A. S. Putra, "DATA ORIENTED RECOGNITION IN BORLAND DELPHI 7.0."

[7] A. S. Putra, "EMBARCADERO DELPHI XE 2 IN GPUPOWERED FIREMONKEY APPLICATION."

[8] A. S. Putra, "HAK ATAS KEKAYAAN INTELEKTUAL DALAM DUNIA TEKNOLOGY BERBASIS REVOLUSI INDUSTRI 4.0."

[9] A. S. Putra, "IMPLEMENTASI PERATURANPERUNDAN GAN UU. NO 31

TAHUN 2000 TENTANG DESAIN INDUSTRI

BERBASIS INFORMATION TECHNOLOGY."

[10] A. S. Putra, "IMPLEMENTATION OF PARADOX DBASE."

[11] A. S. Putra, "IMPLEMENTATION
OF TRADE SECRET

CASE STUDY

SAMSUNG MOBILE PHONE."

[12]

A.S.Putra,"IMPLEMENTATI ON PATENT FOR APPLICATION WEB BASED CASE STUDI WWW. PUBLIKLAMPUNG. COM."

[13] A. S. Putra, "IMPLEMENTATION

SYSTEM FIRST TO INVENT IN DIGITALLY INDUSTRY."

[14] A. S. Putra, "MANUAL REPORT \& INTEGRATED DEVELOPMENT ENVIRONMENT BORLAND DELPHI 7.0."

[15] A. S. Putra, "PATENT AS RELEVAN SUPPORT RESEARCH."

[16] A. S. Putra, "PATENT FOR RESEARCH STUDY CASE OF APPLE. Inc."

[17] A. S. Putra, "PATENT PROTECTION FOR APPLICATION INVENT."

[18] A. S. Putra, "QUICK REPORT IN PROPERTY PROGRAMMING."

[19] A. S. Putra, "REVIEW CIRCUIT LAYOUT COMPONENT 
REQUIREMENT ON ASUS NOTEBOOK."

[20] A. S. Putra, "REVIEW TRADEMARK PATENT FOR INDUSTRIAL TECHNOLOGY BASED 4.0."

[21] A. S. Putra, "TOOLBAR COMPONENT PALLETTE IN OBJECT ORIENTED PROGRAMMING."

[22] A. S. Putra, "WORKING DIRECTORY SET FOR PARADOX 7."

[23] A. S. Putra, "ZQUERY CONNECTION IMPLEMENTED PROGRAMMING STUDI CASE PT. BANK BCA Tbk."

[24] A. S. Putra, D. R. Aryanti, and I.Hartati, "Metode SAW (Simple Additive Weighting) sebagai Sistem Pendukung Keputusan Guru Berprestasi (Studi Kasus: SMK Global Surya)," in Prosiding Seminar Nasional Darmajaya, 2018, vol. 1, no. 1, pp. 85-97.

[25] A. S. Putra and O. M. Febriani, "Knowledge Management Online Application in PDAM Lampung Province," in Prosiding International conference on Information Technology and Business (ICITB), 2018, pp. 181-187.
[26] A. S. Putra, O. M. Febriani, and B. Bachry, "Implementasi Genetic Fuzzy System Untuk Mengidentifikasi Hasil Curian Kendaraan Bermotor Di Polda Lampung," SIMADA (Jurnal Sist. Inf. dan Manaj. Basis Data), vol. 1 , no. 1 , pp. 2130,2018 .

[27] A. S. Putra, H. Sukri, and K.Zuhri, "Sistem Monitoring Realtime Jaringan Irigasi Desa (JIDES) Dengan Konsep Jaringan Sensor Nirkabel," IJEIS (Indonesian J. Electron. Instrum. Syst., vol. 8, no. 2, pp. 221-232.

[28] D. P. Sari, O. M. Febriani, and A. S. Putra, "Perancangan Sistem Informasi SDM Berprestasi pada SD Global Surya," in Prosiding Seminar Nasional Darmajaya, 2018, vol.1, no. 1, pp. 289-294 